\title{
PENERAPAN MITIGASI BENCANA PADA ARSITEKTUR DAN LINGKUNGAN PESISIR DI PULAU SERANGAN PASCAREKLAMASI
}

I Gede Surya Darmawan ${ }^{(1)}$

${ }^{1}$ Dosen Jurusan Arsitektur, Fakultas Teknik dan Perencanaan, Universitas Warmadewa

Email: gdsuryadarmawan@gmail.com

I Wayan Wirya Sastrawan ${ }^{(2)}$

${ }^{(2)}$ Dosen Jurusan Arsitektur, Fakultas Teknik dan Perencanaan, Universitas Warmadewa

Email: wayanwiryasastrawan@gmail.com

\begin{abstract}
Abstrak
Pulau Serangan bisa dikatakan sebagai satu-satunya hasil reklamasi terbesar di Bali yang memiliki berbagai daya tarik wisata seperti adanya Pura Sakenan sebagai salah satu Pura Dhang Khayangan, wisata pantai dan bahari, watersport, budidaya terumbu karang dan rumput laut serta budidaya penyu sehingga Pulau Serangan dikenal dengan sebutan "Pulau Penyu". Tulisan dengan metode penulisan kualitatif deskriptif ini disajikan dengan tujuan untuk mengidentifikasi penerapan mitigasi bencana pada arsitektur dan lingkungan Pulau Serangan pascareklamasi. Hasil analisa didapatkan temuan bahwa wilayah yang paling padat ditinggali penduduk di Pulau Serangan adalah wilayah permukiman penduduk yang berada di sisi barat laut yang notabene wilayah yang paling aman namun tetap beresiko terjadinya bencana gempa disertai tsunami. Penerapan arsitektur dan lingkungan tanggap bencana, Pulau Serangan telah menerapkannya dengan baik terbukti dengan adanya Bangunan Tempat Evakuasi Sementara Tsunami (TES) sekaligus sehari-hari difungsikan sebagai Pasar Desa. Keberadaan TES Tsunami ini sangat vital baik dari sisi tata letak, kapasitas yang bisa ditampung serta sistem evakuasinya. Integrasi lingkungan terhadap keberadaan TES Tsunami ini perlu ditingkatkan seperti penempatan sistem petanda diperbanyak, penempatan zona greenbelt berupa hutan mangrove yang berhadapan dengan laut lepas serta penempatan bebatuan sebagai penahan gelombang air laut juga perlu diperbanyak sehingga dapat mereduksi kecepatan tsunami apabila terjadi sekaligus menjaga ekosistem laut dan darat.
\end{abstract}

Kata Kunci : mitigasi bencana, arsitektur dan lingkungan pesisir, pascareklamasi

\section{PENDAhULUAN}

Pulau Serangan bisa dikatakan sebagai satusatunya tempat di Bali yang telah melaksanakan reklamasi besar-besaran tahun 1995-1998 dengan tujuan untuk membangun fasilitas mega wisata sebagai 'medan magnet' pariwisata baru di Denpasar, meskipun pada kenyataannya reklamasi tersebut harus terhenti karena faktor ekonomi, politik, sosial serta faktor-faktor lainnya. Hingga saat ini, Pulau Serangan terkenal dengan image kawasan sebagai "Pulau Penyu" karena merupakan pusat tempat penangkaran penyu. Selain itu, citra kawasan Pulau Serangan telah terbentuk 
karena adanya Pura Sakenan, wisata pantai dan bahari, watersport, budidaya terumbu karang dan rumput laut, serta terdapatnya kampung nelayan Bugis dan Bali yang menambah daya tarik wisata Pulau Serangan. Terlebih lagi dengan telah dibangunnya jembatan penghubung Pulau Bali dan Pulau Serangan tahun 1998, sangat memudahkan wisatawan menuju Pulau Serangan. Selain itu, adanya isu tentang pembangunan Eco Resort berupa museum, pusat kreativitas, hotel, villa, kawasan marina, dan gedung opera berbentuk kura-kura yang didirikan di tengah laut yang dimulai tahun 2018 tentunya akan lebih menyedot wisatawan lokal dan asing untuk mengunjungi Pulau Serangan (Bali, 2016).

Namun, dibalik banyaknya potensi wisata, ternyata Pulau Serangan memiliki ancaman bencana gempa bumi dan tsunami karena letak pulau berada di pesisir selatan yang menghadap Samudra India serta topografi dan elevasi datan pulau yang relatif rendah yaitu hanya setinggi 1-2 meter dari permukaan air laut yang membuatnya rentan terendam air laut. Selain itu, beberapa ratus kilometer di Selatan Pulau Serangan terletak salah satu zona tumpukan tektonik utama di Bumi (Lempeng Indo-Australia), yang merupakan area sumber utama gempa bumi berpotensi tsunami. Para ahli geologi dan tsunami menganggap Pulau Serangan sebagai salah satu area beresiko tinggi bahaya dampak tsunami di Kota Denpasar di masa depan, karena setiap tsunami besar yang menjangkau Pulau Serangan akan berdampak parah pada penduduk dan pengembangan pariwisatanya (Sutarja, 2015).
Tahun 2014, Pemerintah Provinsi Bali melalui Badan Penanggulangan Bencana Daerah (BPBD) telah membangun salah satu ruang komunal berupa Tempat Evakuasi Sementara (TES) yang terintegrasi dengan pasar Pulau Serangan atas bantuan dana dari Badan Nasional Penanggulangan Bencana (BNPB). Seperti diketahui, bangunan TES berdiri di atas lahan hasil reklamasi laut oleh pihak investor PT. Bali Turtle Island Development (BTID) dan sudah diserahkan untuk menjadi kepemilikan dan pengelolaan dari Desa Pakraman Serangan tahun 1998, melalui kesepatan yang tertuang dalam Momerandum of Understanding (MoU) tanggal 14 Oktober 1998, menjadi pusat aktivitas ekonomi di Pulau Serangan dalam wujud Pasar Desa (Darmawan, 2018). Bangunan ini menjadi satu-satunya bangunan mitigasi bencana gempa disertai tsunami di Pulau Serangan.

Keberadaan bangunan TES Tsunami sebagai mitigasi bencana seharusnya didukung dengan perencanaan arsitektur dan lingkungan yang komprehensif dan bersifat holistic sehingga dapat meminimalisir parahnya dampak dari bencana gempa disertai tsunami. Penerapan mitigasi bencana pada arsitektur pesisir Pulau Serangan setidaknya harus mengakomodir lima konsep perencanaan yaitu perencanaan jalur penyelamatan dan evakuasi, kawasan pelindung, zona aman, ruang terbuka dan vegetasi, serta fasilitas umum dalam permukiman tanggap bencana (Sukawi, 2008). Selain itu penentu tanggap/tidak terhadap bencana pada perencanaan arsitektur suatu kawasan ditentukan oleh fungsi, lokasi, 
orientasi, tipe, dan umur bangunan (Wikantari, 2017).

\section{KAJIAN LITERATUR}

\section{Konsep Perencanaan Arsitektur pada}

\section{Lingkungan yang Tanggap Bencana}

1) Jalur Penyelamatan Evakuasi (Escape Route)

Selain bangunan tahan gempa, yang diperlukan dalam upaya meminimalkan dampak yang dihasilkan oleh bencana adalah perencanaan jalur evakuasi korban bencana. Pada dasarnya perencanaan jalur evakuasi ini ada 2 macam, yaitu jalur evakuasi pada bangunan maupun jalur evakuasi pada lingkungan permukiman.

\section{A. Jalur Evakuasi pada Bangunan / Gedung} Perencanaan jalur evakuasi (escape route) pada bangunan/gedung terutama yang berlantai banyak dilakukan dengan membuat tangga darurat atau list yang dapat langsung berhubungan dengan ruang luar. Biasanya tangga darurat diletakkan pada bagian samping bangunan ataupun tepat di tengah-tengah yang merupakan inti bangunan. Hal ini dimaksudkan agar akses untuk keluar masuk gedung lebih mudah dan aman.

\section{B. Jalur Evakuasi pada Lingkungan Perumahan/Permukiman}

Pada perencanaan suatu permukiman seharusnya dipertimbangkan mengenai sistem perencanaan jalur servis/pelayanan lingkungan. Karena sistem ini merupakan rancangan arus pergerakan dari kendaraan servis (seperti pengangkut sampah, pengangkut barang, kendaraan pemadam kebakaran termasuk juga ambulan) dari suatu kaveling atau blok lingkungan tertentu, yang dipetakan pada hirarki/kelas jalan yang ada pada kawasan perencanaan. Hal ini penting karena apabila suatu ketika terjadi bencana, maka sebisa mungkin kendaraan penyelamat dapat segera menuju lokasi untuk memberi pertolongan. Identifikasi alur penyelamatan jika terjadi bencana:

- Tersedianya jalur pedestrian ke daerah yang lebih tinggi. Jalan untuk jalur evakuasi.

- Pembangunan struktur gedung bertingkat, harus memperhatikan jalur evakuasi yang lebih baik (missal: tangga darurat di luar gedung).

- Tata ruang yang berbasis bencana yang sudah menyiapkan diri dengan tempat dan rute evakuasi bila banjir atau kebakaran atau bencana lainnya terjadi.

- Tata ruang yang berbasis bencana yang sudah menyiapkan diri dengan tempat dan rute evakuasi bila banjir atau kebakaran atau bencana lainnya terjadi.

Selain itu, perlu diperhatikan jalur evakuasi pada bangunan (tangga darurat dan lift) dan lingkungan permukiman (perancangan permukiman yang mempertimbangkan perencanaan jaluar servis/pelayanan lingkungan, pembangunan bangunan penyelamat, pola permukiman yang ditata dengan baik dan sejajar garis pantai, pantai dilindungi tanaman keras seperti bakau dan kelapa. 


\section{2) Kawasan Pelindung}

Identifikasi yang termasuk dalam kawasan pelindung antara lain:

A. Pengadaan zona aman di daerah permukiman.

B. Perencanaan struktur penyangga (tanggul penahan, hutan bakau, dll)

C. Perencanaan zona penyangga produktif (tambak, sawah)

D. Perencanaan jalur hijau berlapis untuk menyaring puing/sampah jika terjadi banjir.

E. Pelestarian alam sebagai bagian dari kawasan penyangga. Tidak melakukan penggundulan hutan. Pada daerah permukiman, dimana telah padat dengan bangunan, sehingga tingkat resapan air ke dalam tanah berkurang, dengan tidak tersedianya daerah resapan yang cukup. Jika terjadi hujan dengan curah hujan yang tinggi menyebabkan sebagian air hujan menjadi air permukaan yang berpotensi menyebabkan banjir.

\section{3) Zona Aman}

Pada perencanaan yang berfungsi sebagai permukiman, harus diperhatikan mengenai segala sesuatu yang menyangkut rencana tata bangunan dan lingkungan. Hal ini dimaksudkan agar penataan lingkungan perumahan dapat lebih optimal. Selain itu dengan adanya penataan tersebut maka juga akan tercipta pemetaan yang jelas mengenai peruntukan lahan. Salah satu yang termasuk dalam tata rencana bangunan dan lingkungan yang perlu diupayakan jika dikaitkan dalam hal bencana, adalah adanya zona aman bencana. Zona aman dapat berupa ruang terbuka pada suatu kawasan permukiman yang pada fungsi sebenarnya dapat sebagai lahan hijau seperti lapangan dan hutan. Dapat pula berupa bangunan keselamatan/mengungsi jika terjadi bencana, yang fungsi sesungguhnya adalah bangunan fasilitas umum.

\section{4) Ruang Terbuka dan Vegetasi}

Terdapat batas antara area pantai dengan area perumahan yang dapat mengurangi tingkat arus air laut yang masuk saat bencana. Batas salah satunya dapat berupa tanaman keras (bakau, nipah, waru, kelapa). Pantai berbentuk lurus dan dilindungi oleh tanaman keras relative baik untuk permukiman. Penggunaan pepohonan untuk menyerap $\mathrm{CO} 2$ serta menurunkan suhu udara sehingga dapat mengurangi penggunaan AC. Antara pantai dengan area perumahan ditanami oleh pepohonan pantai yang kuat dan memiliki volume daun yang lebat (untuk penyerapan $\mathrm{CO} 2$ ).

Pembangunan ruang terbuka (open space) dan taman kota dapat dimaksimalkan yang nantinya dapat dipergunakan sebagai ruang darurat kota. Ruang darurat kota tersebut dilengkapi dengan kebutuhan akan air bersih, KM / WC untuk buang air besar, alat komunikasi dan gudang untuk menyimpan makanan dan obat-obatan untuk beberapa hari sambil menunggu bantuan dating. Sehingga kita tidak lagi mendengar berita pengungsi kelaparan dan tidak makan selama 2 hari atau lebih karena belum mendapat bantuan.

Mewujudkan kota tanggap bencana dapat dilakukan dengan memperbanyak vegetasi di 
taman kota yang merupakan habitat hewan liar seperti burung dan serangga lain yang dapat juga berfungsi sebagai peringatan dini terhadap bencana. Kita perlu belajar banyak dari masyarakat kaki Gunung Merapi untuk menumbuhkan kepekaan terhadap perubahan alam yang ditandai dengan prilaku hewan liarnya.

\section{5) Fasilitas Umum dalam Permukiman Tanggap Bencana}

Pada area pinggiran kota, fasilitas umum (pertokoan, sekolah, gedung pertemuan warga) yang melayani area permukiman dikelompokkan dekat dengan rumah-rumah yang membutuhkannya. Sehingga para penghuni tidak perlu mengendarai kendaraan bermotor mereka untuk mencapainya. Sementara di kota-kota besar, layout polisentris (multi pusat) kota dapat mengurangi jarak tempuh dari area pinggiran kota ke fungsi-fungsi utama (komersial, pusat pemerintahan, dll) yang terletak di pusat kota. Fasilitas umum diletakkan pada jarak yang aman dan posisi sentral dari perumahan sehingga mudah dicapai. Disediakan sejumlah pusat-pusat fasilitas umum untuk sejumlah unit perumahan yang dilayaninya.

\section{Konsep Penataan Ruang Kota Pantai}

Konsep penataan ruang kota pantai yang perlu diperhatikan pada kota antara lain (Edyanto, 2011):

1) Perlindungan dalam kawasan pembatas kota dan garis pantai akan mempertahankan perlindungan alam dalam bentuk hutan bakau sebagai sabuk hijau alam (green belt) yang akan melindungi hantaman gelombang tsunami ketika mencapai daratan sehingga gerakan air dapat diperlambat karena adanya hutan bakau.

2) Perlindungan lain di garis pantai adalah pembangunan dinding penahan secara horizontal maupun vertikal yang akan berfungsi sebagai penahan gelombang dan memperlemah daya desak air kearah daratan.

3) Pembangunan fisik perkotaan perlu untuk ditata kembali dengan mempertimbangkan struktur bangunan, tata letak dan perlindungan terhadap desakan air yang masuk ke dalam kota serta mengurangi sebanyak mungkin jalur jalan yang vertikal terhadap garis pantai serta membangun bangunan secara linier pada jalan yang sejajar dengan garis pantai.

4) Perlindungan terhadap sempadan pantai.

\section{HASIL DAN PEMBAHASAN}

Penerapan Mitigasi Bencana pada Arsitektur Pesisir di Pulau Serangan Pascareklamasi

Dalam membahas peneran mitigasi bencana pada arsitektur pesisir di Pulau Serangan Pascareklamasi, dikolaborasikan dua teori yang telah dipaparkan sebelumnya sehingga didapatkan detail pembahasan mengenai upaya mitigasi bencana dari sudut pandang arsitektur dan lingkungan pesisir, yaitu :

\section{1) Adanya Jalur Penyelamatan Evakuasi}

Sebelum mengidentifikasi jalur penyelamatan dalam upaya mitigasi bencana di Pulau Serangan, terlebih dahulu diidentifikasi 
wilayah Pulau Serangan terbagi menjadi tiga zonasi yang rawan bencana tsunami yaitu wilayah milik investor PT. BTID yang berada di sebelah kanan kanal wisata masuk dalam kategori wilayah yang cukup beresiko dan sangat beresiko terkena bahaya tsunami karena berhadapan langsung dengan laut lepas. Untungnya, wilayah ini sebagian besar hanya terdiri dari lahan kosong berpasir dan ditumbuhi oleh tanaman liar. Sedangkan wilayah permukiman penduduk yang berada di sebelah kiri kanal termasuk wilayah aman beresiko terkena tsunami. Wilayah ini terdiri dari 7 Banjar Adat dan Dinas serta 1 Kampung Bugis.

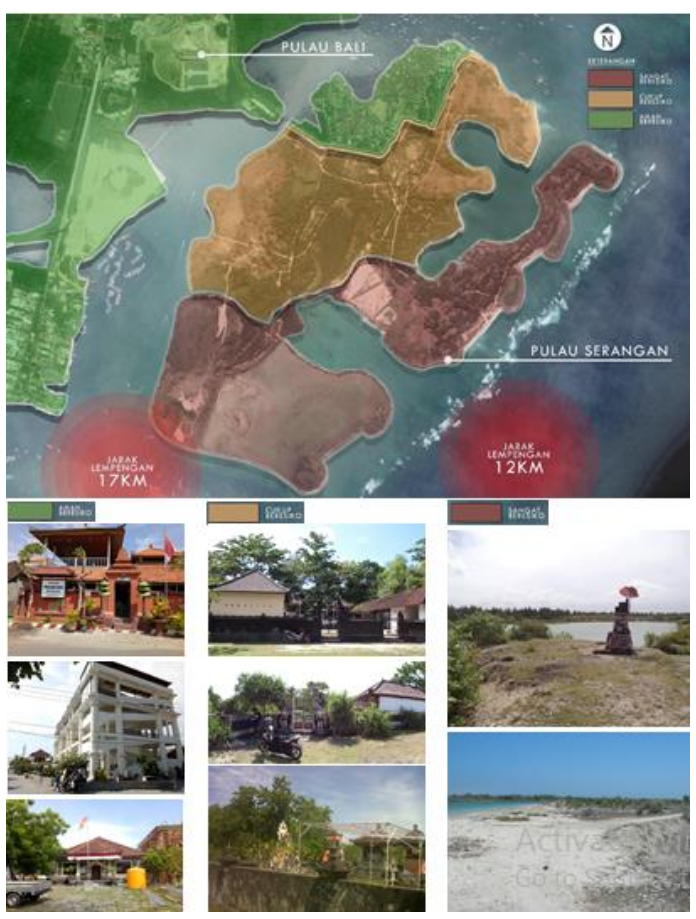

Gambar 1 Analisa zonasi wilayah rawan tsunami

(Sumber: Dokumentasi Pribadi, 2020)

Berdasarkan analisa dari wilayah yang diduga mendapat prioritas bahaya tertinggi (sangat beresiko) hingga prioritas paling rendah (aman beresiko) terhadap bencana tsunami, selanjutnya diidentifikasi letak-letak bangunan berlantai 1, 2, 3, dan 4 untuk mendapatkan kemungkinan titik-titik bangunan yang dapat dijadikan sebagai tempat evakuasi darurat saat terjadi tsunami.

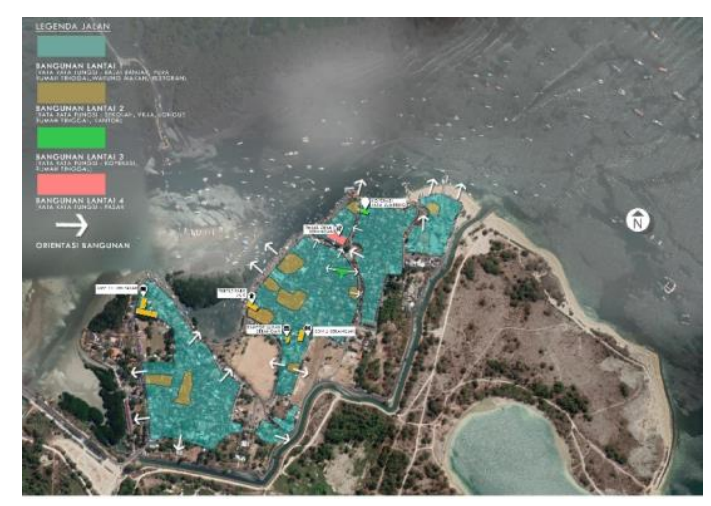

Gambar 2 Pemetaan Ketinggian Bangunan pada Wilayah Permukiman Penduduk (Sumber: Dokumentasi Pribadi, 2020)

Terkait dengan lokasi bangunan Pasar/TES Tsunami di Pulau Serangan, jalur evakuasi yang memanfaatkan jalan-jalan lokal telah dirancang dengan baik dengan pola permukiman yang tegak lurus dengan jalur pantai. Masyarakat yang tinggal pada 7 banjar dan 1 kampung bugis berada hampir mengelilingi bangunan TES tsunami, sehingga andaikata terjadi tsunami, masyarakat dapat mempersingkat waktu mengungsi ke bangunan Pasar/TES tsunami. Sedangkan zonasi permukiman yang berada dekat dengan Pura Sakenan, dapat mengungsi ke bangunan TES Tsunami atau menuju zona aman yaitu ke Kantor BKN Denpasar yang berada di Jl. Bypass Ngurah Rai. 


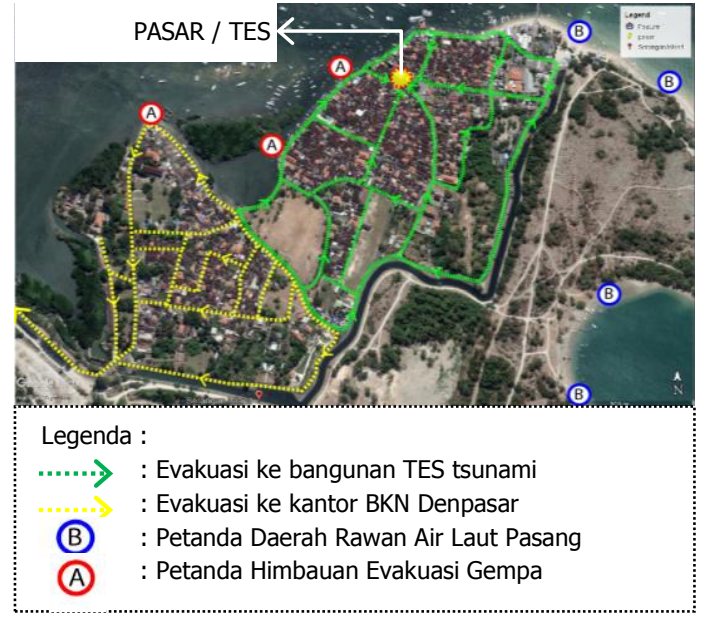

Gambar 3 Peta Evakuasi Gempa Bumi dan Tsunami

(Sumber: Dokumentasi Pribadi, 2020)

Pada bangunan Pasar/TES tsunami, jalur evakuasi menuju lantai 3 dan 4 menggunakan jalan miring (ramp) lebar 2 meter sehingga mempercepat evakuasi. Terdapat sistem petanda disepanjang ramp dan bordes sebagai pemandu jalan menuju lantai 3. Di lantai puncak yaitu lantai 4 terdapat tempat terbuka yang selain menampung masyarakat Pulau Serangan, juga sebagai heliport (tempat pendaratan helicopter) BPBD untuk mengevakuasi masyarakat menuju keluar dari Pulau Serangan.

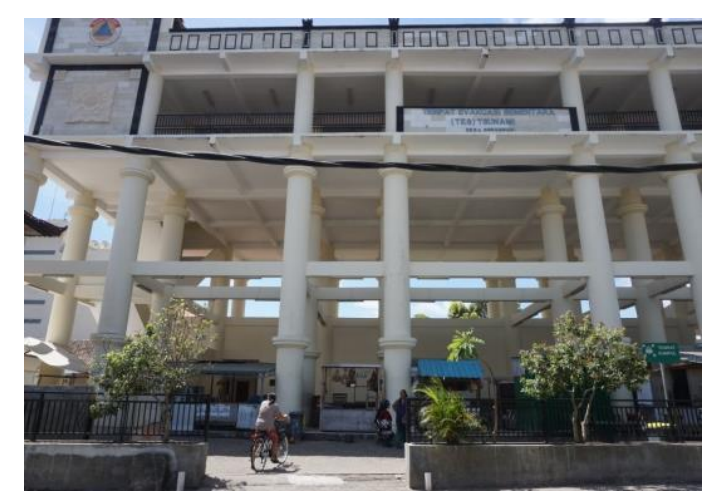

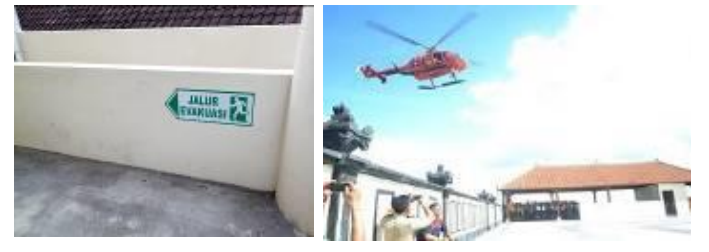

Gambar 4 Akses Evakuasi pada TES Tsunami

(Sumber: Dokumentasi Pribadi, 2020)

2) Kawasan Pelindung termasuk Sabuk Hijau Alam (Green Belt) serta dinding penahan pantai

Secara tata ruang, penempatan kawasan pelindung yaitu berupa lahan kosong yang terdiri dari lahan berpasir dan tumbuhan liar secara tidak sengaja telah sesuai penempatannya yaitu berhadapan langsung dengan lepas pantai. Sebaliknya, lahan permukiman penempatannya berada disisi paling jauh dari lepas pantai. Lahan kosong ini merupakan lahan hasil reklamasi milik PT. BTID yang sampai saat ini belum termanfaatkan. Diharapkan pihak investor tidak membangun fasilitas massif dalam bentuk bangunan hunian di pinggir lepas pantai yaitu di sisi Timur dan Selatan Pulau Serangan karena sangat beresiko tekena dampak paling besar apabila terjadi bencana tsunami. Sebaiknya ditanam tumbuhan yang berfungsi sebagai green belt contohnya tanaman mangrove. 


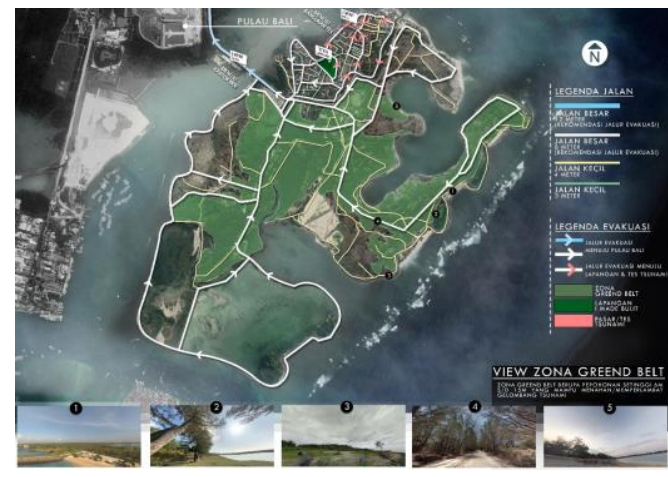

Gambar 5 Zona Greenbelt yang sebaiknya dikonservasi dengan ditanam Hutan Mangrove.

(Sumber: Dokumentasi Pribadi, 2020)

\section{3) Zona Aman}

Penempatan lokasi bangunan Pasar sekaligus TES tsunami telah memperhatikan dari segi cakupan/lingkup wilayah yang akan dievakuasi. Apabila terjadi indikasi gempa bumi yang berpotensi tsunami, setidaknya wilayah utara dan timur Pulau Serangan yang berbatasan langsung dengan laut dapat segera evakuasi ke Pasar/TES tsunami. Dalam keadaan darurat, setidak-tidaknya warga dari 5 banjar yaitu Banjar Ponjok, Kaja, Tengah, Kawan, Peken dan Kampung Bugis dapat mengungsi di bangunan ini. Apabila waktu masih memungkinkan, tentunya lebih baik mengungsi keluar Pulau Serangan.

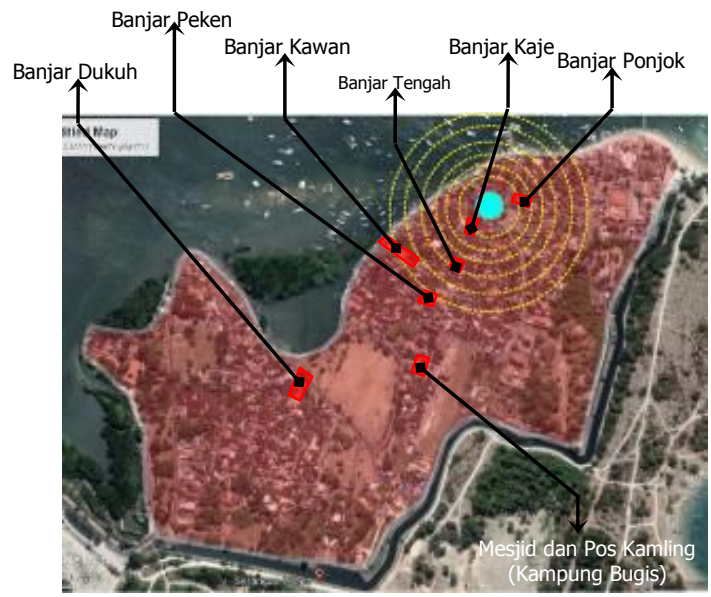

Gambar 6 Cakupan Wilayah Evakuasi Tsunami

(Sumber: Dokumentasi Pribadi, 2020)
4) Ruang Terbuka dan Fasilitas Umum dalam Permukiman Tanggap Bencana

Pada konteks lingkungan sekitar pendukung bangunan Pasar/TES tsunami, terdapat 2 ruang terbuka yang terdapat disebelah timur Pasar/TES tsunami dan di sebelah barat Kampung Bugis. Sehari-hari, ruang terbuka sekaligus fasilitas umum tanggap bencana ini dimanfaatkan sebagai tempat parker Pura Dalem Cemara dan Pura Segara, dan tempat jogging dan mengadakan kegiatan outbond seperti perkemahan, lomba 17 agustus dan tahun baru dan kegiatan masyarakat lainnya. Penempatan zona ruang terbuka dan lapangan ini ditempatkan di wilayah permukiman padat penduduk.

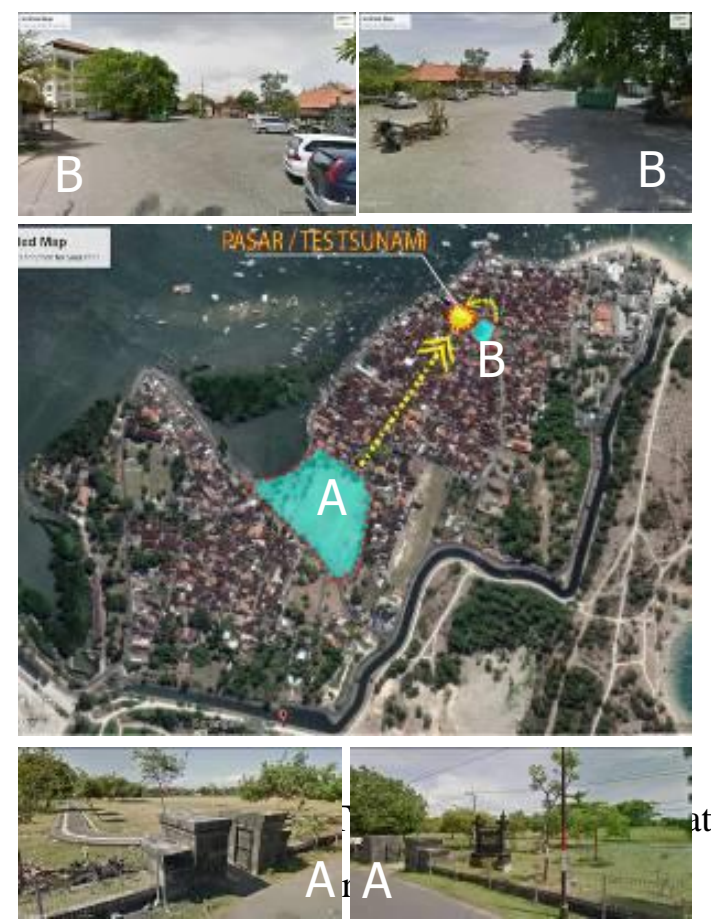

(Sumber: Dokumentasi Pribadi, 2020)

5) Pembangunan fisik yang mempertimbangkan struktur bangunan, tata letak dan perlindungan terhadap desakan air yang masuk ke dalam kota serta mengurangi sebanyak mungkin jalur jalan 
yang vertikal terhadap garis pantai serta membangun bangunan secara linier pada jalan yang sejajar dengan garis pantai.

Terkait dengan fungsi bangunan sebagai pasar (penggerak roda perekonomian), sangat cocok bermulti fungsi sebagai tempat evakuasi tsunami karena pasar yang notabene menjadi medan magnet masyarakat di Pulau Serangan. Selain itu, letak dari Pasar Desa di tengahtengah wilayah permukiman memudahkan evakuasi dari segala arah. Selain sebagai pasar dan tempat evakuasi tsunami, pada lantai 3 bangunan, sehari-hari difungsikan sebagai tempat bermain anak-anak sekaligus ruang terbuka semi indoor. Lantai 2 difungsikan sebagai void sehingga pasar terasa lebih lega dari sisi ketinggian. Hal tersebut menjadikan bangunan ini sangat ramah terhadap berbagai usia dan kalangan masyarakat.

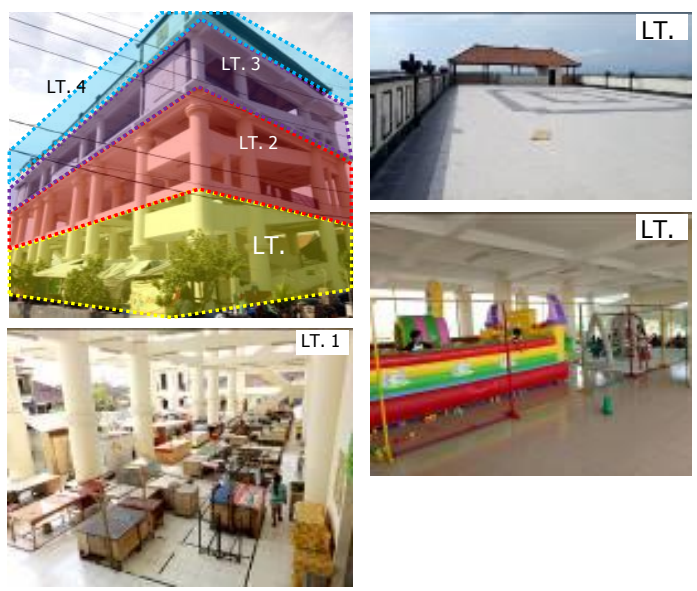

Gambar 8 Efektivitas Fungsi Lt 1-4 (Sumber: Dokumentasi Pribadi, 2020)

Dari segi lokasi pada peta, posisi Pasar/TES tsunami cenderung berada agak ke pinggir pesisir laut dibandingkan radius dan deliniasi dari wilayah permukiman penduduk. Namun, apabila dilihat dari kedekatan terhadap wilayah permukiman terdapat, posisi
Pasar/TES tsunami berada hamper di tengahtengah wilayah padat hunian. Sedangkan arah hadap/orientasi bangunan mengarah ke sisi timur dan selatan, yang mana sisi tersebut merupakan jalur evakuasi dan area berkumpul masyarakat sebelum menaiki gedung Pasar/TES tsunami. Orientasi dari segi bentuk pulau juga sudah serah dan tegak lurus dengan arah pesisir pantai baik yang berbatasan dengan laut dangkal maupun laut dalam. Sehingga saat terjadi tsunami, bangunan tidak menghadang gelombak air tsunami karena berada sejajar dengan pola permukiman. Lokasi Pasar/TES tsunami memang diprioritaskan berada di wilayah Bali Selatan karena merupakan zona wilayah merah yang rawan potensi tsunami.

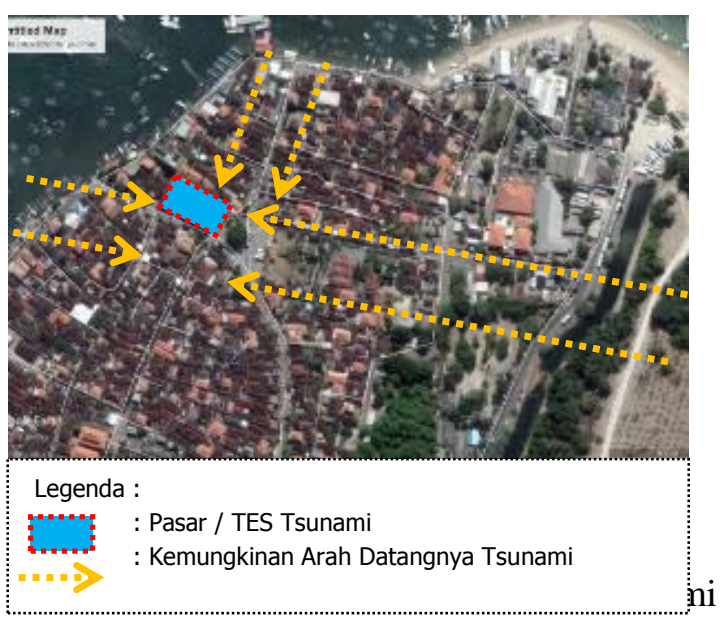

(Sumber: Dokumentasi Pribadi, 2020)

Tipe bangunan Pasar/TES tsunami merupakan bangunan tidak berpanggung berlantai 4. Dari segi bentuk, bangunan ini telah menerapkan bentuk denah atau potongan sederhana yaitu berbentuk persegi panjang dengan ukuran $40 \mathrm{x}$ 16 meter yang sesuai dengan salah satu terapan konsep bangunan tahan gempa. Proporsi bangunan yaitu perbandingan 
panjang lebar dan tinggi bangunan juga sudah sesuai yaitu 40 meter panjang : 16 meter lebar : 15 meter tinggi. Modul struktur kolom yang dipergunakan bervariasi yaitu modul 4, 5, 7, dan 8 meter. Modul struktur ini merupakan modul standar yang umum digunakan pada konstruksi gedung bahan beton bertulang, sehingga terlihat seperti bangunan kotak-kotak yang disusun. Akibatnya, resiko bangunan rusak menjadi minimal karena tubrukan prilaku modul struktur dapat diminimalisir.

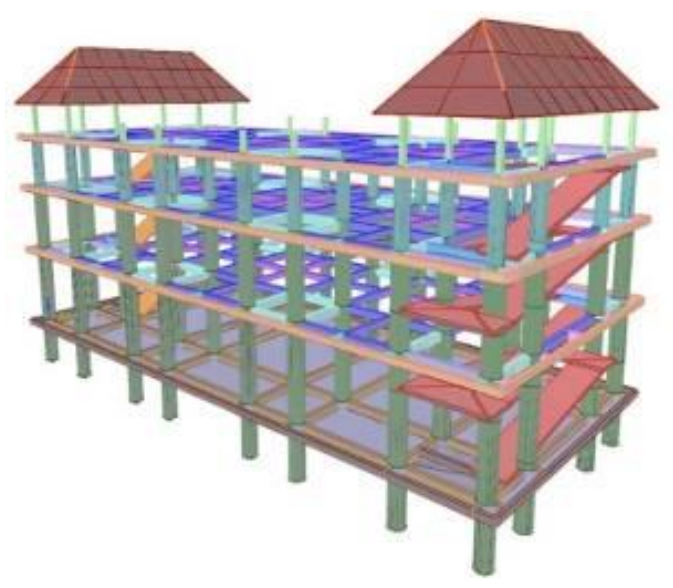

Gambar 10 Permodelan Struktur Bangunan TES Tsunami dalam Wujud 3 Dimensi (Sumber: Sutarja, 2015)

Kelengkapan komponen-komponen bangunan juga menjadi tolak ukur dalam konsep bangunan tahan gempa. Pada bangunan Pasar/TES tsunami, komponen bangunan telah lengkap karena terdiri dari kepala (rangka dan penutup atap), badan/tubuh (dinding dan kolom), dan kaki (pondasi). Sambungan antarkomponen antara pondasi dengan kolom, kolom dengan atap, dan kesatuan antarkolom dengan sloof dan balok cincin (ring balok) yang saling terkait sehingga bila terjadi gempa dapat stabil. Dari sisi usia, umur bangunan Pasar pasca renovasi total menjadi bangunan multi fungsi TES tsunami juga terbilang masih sangat baru karena baru didirikan tahun 2014 . Menurut Kepala Pusat Pengendali dan Operasi (Pusdalops) BPBD Bali, I Gde Made Jaya Serataberana, bangunan yang didirikan diatas lahan 6 are ini juga memiliki keistimewaan karena tahan gempa dan ancaman dari tsunami yang mencapai 12 meter. Dengan tinggi bangunan mencapai 15 meter, sesuai dengan peraturan gubernur (Pergub) juga disesuaikan dengan kajian tsunami yang mungkin terjadi mencapai ketinggian 12 meter karena sudah terhambat oleh Pulau Nusa penida, Perbukitan Uluwatu dan kawasan Mangrove.

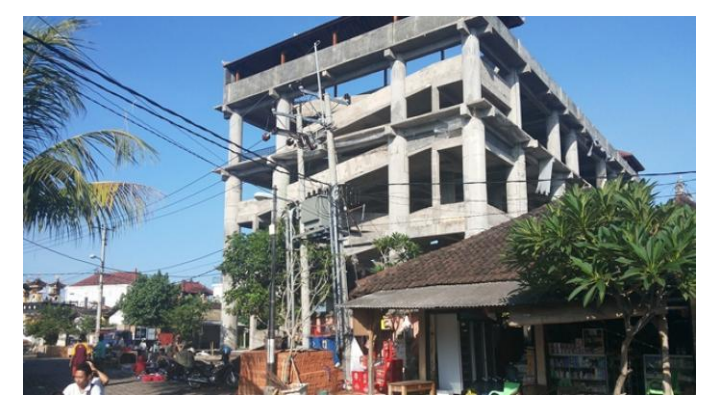

Gambar 11 TES Tsunami pada Tahap Pengerjaan Struktur Bangunan (Sumber: Tribun Bali, 2018)

6) Perlindungan Terhadap Sempadan Pantai Secara umum, perlindungan terhadap sempadan pantai di Pulau Serangan sudah terlaksana dengan baik terutama didi timur dan selatan pulau yang berhadapan langsung dengan laut lepas, tidak terdapat bangunanbangunan. Hanya terdapat beberapa warung dengan struktur semi permanen saja yang terdapat disana untuk mengakomodir kebutuhan para pemancing dan pelancong yang ingin berwisata disana. Sedangkan pantai sisi utara dan barat, hampir sebagian besar tidak menerapkan adanya sempadan bangunan 
yang sesuai yaitu 100 meter dari bibir pantai. Seluruh bangunan yang melanggar sempadan pantai tersebut sebagian besar didominasi oleh bangunan permukiman warga setempat. Hal ini bisa dimaklumi karena sisi utara dan barat berbatasan langsung dengan Pulau Bali yang mana tidak terdapat ancaman langsung tsunami dari laut lepas yang berada di sisi timur dan selatan.

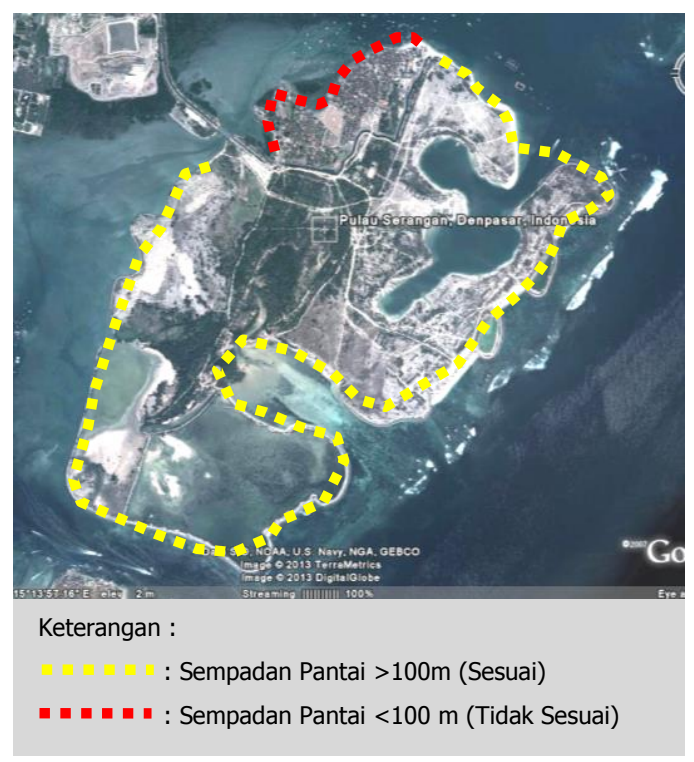

Gambar 12 Penerapan sempadan di sepanjang pantai

(Sumber: Hasil Analisa, 2020)

Menurut ramalan dan isu tentang ancaman bahaya tsunami di Pulau Serangan dengan ketinggian mencapai 12 meter, kemungkinan besar hanya bangunan berlantai 3 dan 4 di wilayah permukiman penduduk saja yang dapat dijadikan sebagai tempat evakuasi sementara. Posisi dari bangunan berlantai 3 dan 4 sebagian besar berada di wilayah dekat dengan Pasar. Bangunan Pasar merupakan bangunan berlantai 4 yang difungsikan pula sebagai Tempat Evakuasi Sementara (TES) Tsunami. Sedangkan bangunan-bangunan berlantai 3 difungsikan sebagai rumah tinggal.
Permasalahan topografi bangunan yang relative rendah dan nyaris sejajar dengan permukaan laut menjadi alasan mengapa rendahnya kuantitas bangunan-bangunan berlantai 2 terlebih lagi berlantai 3 dan 4 .

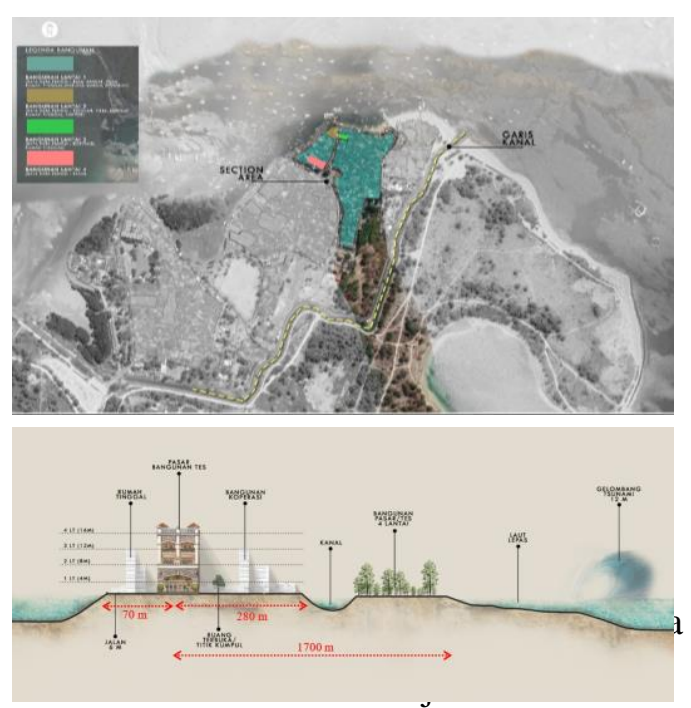

(Sumber: Dokumentasi Pribadi, 2020)

Berdasarkan gambar diatas, terlihat bahwa hanya terdapat kurang lebih 2 bangunan yang memiliki ketinggian 4 lantai yang kemungkinan dapat digunakan tempat evakuasi sementara terhadap bencana tsunami. Keberadaan bangunan ini sebaiknya didukung dengan system petanda yang mengarahkan masyarakat yang berada di Pulau Serangan untuk menuju bangunan ini ataupun keluar dari Pulau Serangan melewati jembatan penghubung Pulau Bali dengan Pulau Serangan. 


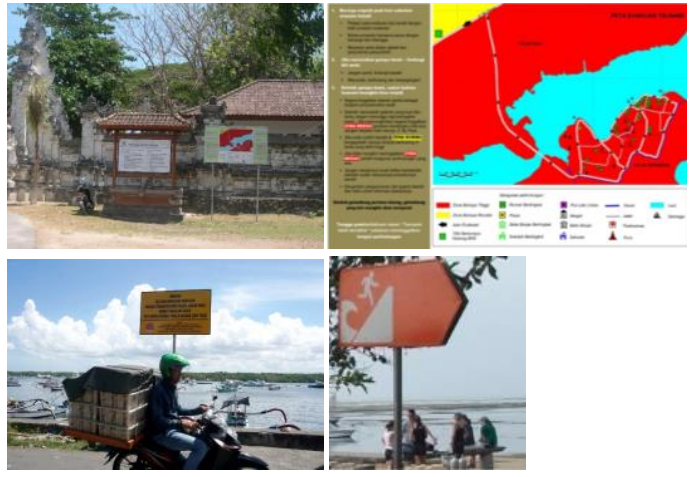

Gambar 14 Beberapa petanda tentang bahaya tsunami dan tempat evakuasinya (Sumber: Dokumentasi Pribadi, 2020)

Lokasi-lokasi penempatan system petanda ini diletakkan disepanjang jalan lingkungan mengitari wilayah permukiman penduduk. Seperti diketahui bahwa jalan lingkungan di wilayah permukiman penduduk berada mengitari wilayah permukiman penduduk yaitu berada di pinggir yang berbatasan lsngsung dengan pesisir Pulau Serangan. Selain itu, pada Pura-Pura Dhang Khayangan Jagat seperti Pura Sakenan dan Pura Dalem Susunan Wadon juga ditempatkan system petanda peringatan dini bahaya tsunami tersebut. Diharapkan dengan adanya system petanda ini dapat meminimalisir jatuhnya korban jiwa akibat kemungkinan musibah gempa yang disertai tsunami menerjang Pulau Serangan.

\section{KESIMPULAN}

Penerapan mitigasi bencana pada arsitektur dan lingkungan di Pulau Serangan pascareklamasi telah menerapkannya dengan baik terbukti dengan adanya Bangunan Tempat Evakuasi Sementara Tsunami (TES) sekaligus sehari-hari difungsikan sebagai Pasar Desa. Keberadaan TES Tsunami ini sangat vital baik dari sisi tata letak, kapasitas yang bisa ditampung serta sistem evakuasinya. Integrasi lingkungan terhadap keberadaan TES Tsunami ini perlu ditingkatkan seperti penempatan sistem petanda diperbanyak, penempatan zona greenbelt berupa hutan mangrove yang berhadapan dengan laut lepas serta penempatan bebatuan sebagai penahan gelombang air laut juga perlu diperbanyak sehingga dapat mereduksi kecepatan tsunami apabila terjadi sekaligus menjaga ekosistem laut dan darat.

\section{REFERENSI}

Bali, T. (2016, Desember 9). Eco Resort Serangan Sedot 50.000 Tenaga Kerja, Januari 2017 Genjot Pembangunan.

Retrieved from http://bali.tribunnews.com: http://bali.tribunnews.com/2016/12/09 /eco-resort-serangan-sedot-50000tenaga-kerja-januari-2017-genjotpembangunan?page=all

Darmawan, I. G. (2018). Faktor-Faktor Pengaruh Perubahan Penggunaan Lahan Ulayat Akibat Reklamasi di Pulau Serangan. Undagi, 6, 37-44.

Edyanto, C. H. (2011). Analisa Kebijakan Penataan Ruang Untuk Kawasan Rawan Tsunami di Wilayah Pesisir. Jurnal Teknologi Lingkungan Deputi Bidang Pengembangan Kekayaan Alam, 10.

Kompas. (2017, 4 14). Bali Dinobatkan sebagai Destinasi Wisata Terbaik di Dunia. Retrieved from https://travel.kompas.com: 
https://travel.kompas.com/read/2017/0

4/14/200540027/bali.dinobatkan.sebag

ai.destinasi.wisata.terbaik.di.dunia

Lynch, K. (1975). The Image of The City. London: The MIT Press.

Sukawi. (2008). Menuju Kota Tanggap

Bencana (Penataan Lingkungan

Permukiman Untuk Mengurangi

Resiko Bencana. Semarang: Jurusan

Arsitektur Fakultas Teknik UNDIP.

Sutarja, I. N. (2015). Rencana Tempat

Evakuasi Sementara (TES) Pada

Kawasan Rawan Bencana Tsunami

Provinsi Bali. Denpasar: Universitas

Udayana.

Wikantari, R. (2017). Model tata Ruang dan

Bangunan Tanggap Bencana di Pulau

Kecil Kasus Pulau Samalona,

Makassar. Makassar: Universitas

Hassanuddin. 